\title{
Original article (full paper) \\ The influence of rules manipulation on offensive patterns during small-sided and conditioned games in football
}

\author{
João Cláudio Machado \\ Chellsea Alcântara \\ Carlos Palheta \\ João Otacílio Libardoni dos Santos \\ Universidade Federal do Amazonas, Manaus, AM, Brasil \\ Daniel Barreira \\ Universidade do Porto, Porto, Portugal \\ Alcides José Scaglia \\ Universidade Estadual de Campinas, Limeira, SP, Brasil
}

\begin{abstract}
This study analyzed the influence of rules manipulation on offensive patterns in different Small-Sided and Conditioned Games (SSCGs). Fourteen young soccer players (13.82 \pm 1.94 years) performed two different SSCG formats $(6 \mathrm{v} 6+\mathrm{Gk})$ : Maintenance of Ball Possession Game (MPG) and Progression to the Target Game (PTG). Both games were played on a field $52 \mathrm{~m}$ long by $32 \mathrm{~m}$ wide. We used the Offensive Sequences Characterization System (OSCS) and SoccerEye software to analyze offensive sequences. For statistical analysis, we used the Mann-Whitney test to compare variables that compose the OSCS between the two SSCGs, while the SDIS-GSEQ software allowed us to detect offensive patterns. We concluded that the rule manipulation of SSCGs influenced changes in teams' offensive patterns, in which they self-organized according to manipulation of key task constraints.
\end{abstract}

Keywords: football, constraints-led approach, tactical behavior

\section{Introduction}

A football match can be understood as a complex and dynamic system because multiple sources of information influence many decisions, actions, and interactions among the system's components ${ }^{1,2}$. Despite performance based in a complex inter-relation among physical, technical, tactical, and psychological aspects, due to the game's high variability and contextual complexity, tactical, perceptual, and decision-making components are highlighted as essential to players and teams' performance.

According to Costa, Guilherme Oliveira, and Garganta ${ }^{3}$, tactics in football can be understood by how players and teams manage game space through constant movements and their positioning, according to different match contexts. Teams and players' behavior depends on their interpretation of a large amount of relevant information that emerges from the match context. This information originates from interaction of four classes of constraints (Organismic, Team, Environment, and Tasks), providing players' perception of opportunities for action (affordances) 4,5 $^{\text {. }}$ Thus, as interpersonal coordination occurs, players must share their perceptions of affordances, with players coordinating action possibilities that one player provides to another, thus establishing interpersonal synergies ${ }^{6}$.
Thus, when handling a task constraint, the coach leads players to perceive different sources of contextual information, providing the team with self-organization toward new possibilities for action, that is, new tactical behaviors emerging from formation of new interpersonal synergies ${ }^{6,7}$. In this sense, task constraints are important tools for enhancing players' decisions and actions in the game environment, as well as for shaping players and teams' tactical behavior ${ }^{8}$.

Therefore, Small-Sided and Conditioned Games (SSCGs) are an excellent example of task constraints manipulation that enable coaches to shape specific tactical behaviors through modifications and adaptations of the competitive context ${ }^{9,10}$. SSCGs allow coaches to manipulate several constraints, for example, field dimension, the player's number, game rules, and others, to stimulate different self-organization processes in which players must adapt according to new action possibilities generated from perception of new information sources ${ }^{10,11}$. In addition, SSCGs provide players maintenance of an environment similar to regular competition, in contrast to traditional teaching and training methodology $y^{12,13}$.

However, to reach efficiency in the teaching and training process, the coach must have some knowledge that allows him to manipulate key task constraints, thus influencing emergence 
of specific tactical behaviors aligned with training aims and the game model he has defined ${ }^{11,14}$. In recent years, due to technological and methodological developments that allow investigation of emerging coordinative patterns in team sports, particularly in football, research has attempted to analyze the influence of key task constraint manipulations, such as field dimension and number of players ${ }^{15-17}$.

As for SSCG rules manipulation, Dellal, Chamari, Owen, Wong, Lago-Peñas, and Hill-Haas ${ }^{18}$ found that reducing the amount of ball touches allowed each professional player in different SSCGs tended to decrease the number of successful passes and to increase the amount of lost ball possessions. Thus, the authors ${ }^{18}$ emphasized that manipulating this specific rule makes it possible to prepare players better to deal with more complex situations in football matches.

Almeida, Ferreira, and Volossovitch ${ }^{19}$ investigated the influence of rules manipulation on teams' offensive performance in different SSCGs $(3 \mathrm{v} 3+\mathrm{Gk})$; they found that "two touches" rule would condition players to perceive information and make decisions quickly, while "four passes" rules would induce longer offensive sequences, favoring occurrences of an attack method that prioritized maintenance of ball possession. Studying SSCGs, Lizana, Reverdito, Brenzikofer, Macedo, Misuta, and Scaglia $^{20}$ also found that the manipulation of different game rules influenced teams' technical-tactical performance.

However, not enough information yet exists about rule manipulation's influence on offensive patterns performed by teams during different SSCGs. Therefore, this study analyzes the influence of rules manipulation on teams' offensive patterns in different SSCGs. Thus, SSCG manipulations are intended to assist coaches in developing more specific exercises, thereby increasing the probability of transferring certain tactical behaviors to competitive games.

\section{Methods}

\section{Study Design:}

This research employed observational methodology because it allows observation and recording of team and players' behavior in natural match contexts ${ }^{21}$. This study's design, according to a specific taxonomy ${ }^{22}$, is nomothetic (two teams observed in each SSCG), has follow-up (registration is continuous during the SSCG), and is multidimensional (the observation tool comprises seven field criteria combining field formats with systems of categories).

\section{Subjects:}

Fourteen young soccer players (13.82 \pm 1.94 years) on a team in the city of Manaus-AM participated in this study. The team and players were informed of the experimental study protocol as they signed the free and informed consent form (ICF), approved by the Ethics Committee in Research of the Federal University of Amazonas (CAE: 31081614.6.0000.5020).

\section{Procedures:}

Two different formats of SSCG were used-Maintenance of Ball Possession Game (MPG); Progression to the Target Game (PTG) - by Lizana, Reverdito, Brenzikofer, Macedo, Misuta, and Scaglia ${ }^{20}$. Each of the SSCGs lasted 30 minutes and was performed in a field dimension of $52 \mathrm{~m}$ long and $32 \mathrm{~m}$ wide (Figure 1); teams were composed of six players and a goalkeeper (6v6+Gk). All SSCGs were played between 09:00 and 10:00 a.m., at 48-hour intervals. For each SSCG, two familiarization games (i.e., a period during which players became accustomed to the proposed rules) and two experimental games were played, with a 48-hour interval between them. Games were preceded by a standardized warm-up of 15 minutes, with 5 minutes each of acyclic low-intensity movements and coordinative running, of dynamic stretching, and of intermittent high-intensity activities. During data collection of these games, 173 offensive sequences were recorded from the MPG and 196 from the PTG.

Table 1 contains the different rules included in the two SSCG formats used in this investigation.

The rules used in the MPG and PTG emphasized operational principles of maintaining ball possession and progression to the target, respectively ${ }^{23}$. Importantly, with the exception of the rule that determines the minimum number of passes needed to perform a goal shot in the MPG, breaking the game's rules did not interrupt game dynamics, but some minimum points were given to the opposing team.

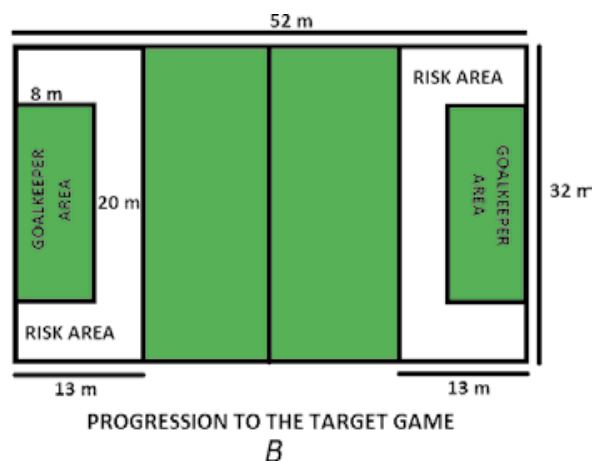

$B$

Figure 1. Field dimensions used at the different SSCG. 
Table 1. Rules included in the different SSCGs used in this study.

\begin{tabular}{|c|c|c|}
\hline $\begin{array}{l}\text { Small-Sides and } \\
\text { Conditioned Games }\end{array}$ & Rules & Definition \\
\hline \multirow{4}{*}{$\begin{array}{l}\text { Maintenance of } \\
\text { Ball Possession } \\
\text { Game (MPG) }\end{array}$} & First Rule & $\begin{array}{l}\text { Each player could do a maximum of two touches on the ball, where extra points to the opposing team } \\
\text { were registered for each extra touch on the ball given by the same player. }\end{array}$ \\
\hline & $\begin{array}{l}\text { Second } \\
\text { Rule }\end{array}$ & $\begin{array}{l}\text { The players of the team who were with the ball possession should make constant switches of lines/ } \\
\text { zones, which were pre-determined in the field with cones of different colors, and were registered an } \\
\text { extra point to the team that could circulate the ball from one side path to the other. }\end{array}$ \\
\hline & Third Rule & $\begin{array}{l}\text { Each time that the team that was with the ball possession could make five passes without returning the } \\
\text { ball to the player who had just made the pass, the team obtained two points. }\end{array}$ \\
\hline & Fourth Rule & The goal could only be scored after five passes, thus earning eight points. \\
\hline \multirow{3}{*}{$\begin{array}{l}\text { Progression to the } \\
\text { Target Game (PTG) }\end{array}$} & First Rule & $\begin{array}{l}\text { The passes made by the players could only be carried out towards the opposing goal, in which each } \\
\text { time the player disrespected this rule it would result in an extra point given to the opposing team, being } \\
\text { allowed the performance of backwards passes only on two occasions, in the recovery of the ball posses- } \\
\text { sion and in an assistance }\end{array}$ \\
\hline & $\begin{array}{l}\text { Second } \\
\text { Rule }\end{array}$ & $\begin{array}{l}\text { Every goal scored made through a backwards pass would worth five points, while the goal scored in } \\
\text { an offensive sequence in which the last pass were performed just towards the opposing goal it would } \\
\text { worth ten points }\end{array}$ \\
\hline & Third Rule & $\begin{array}{c}\text { Whenever the team could break into a pre-defined area by the cones (risk area) would obtain } \\
\text { three points. }\end{array}$ \\
\hline
\end{tabular}

\section{Observation Instrument:}

In this study, two observational instruments were used to characterize and detect offensive patterns by teams in each SSCG: the Offensive Sequences Characterization System (OSCS) and SoccerEye. Those instruments have been properly validated and tested in different studies published elsewhere ${ }^{19,24-26}$.

The OSCS is composed of simple indicators previously used in other investigations: Duration of Ball Possession ${ }^{27}$, number of Players involved ${ }^{28}$, number of Ball Touches ${ }^{28}$, number of Passes $^{29}$, and number of Shots $^{27}$. A simple ratio established between performance indicators makes it possible to access more accurate information about characteristics of teams' offensive sequences ${ }^{19}$. The OSCS has the following composite indicators: Players involved/Duration of ball possession, Ball Touches/ Duration of ball possession, Passes/Duration of ball possession,
Ball Touches/Players involved, Passes/Players involved, Passes/ Ball Touches, and Goal/Shots.

To detect teams' offensive patterns, we also used the SoccerEye observation instrument (Table 2) 25 $^{25}$, consisting of 80 unique, mutually exclusive categories, distributed according to seven criteria that combine field formats with systems of categories: (1) Start of the offensive phase/ball recovery (BR); (2) Development of defense/attack transition-state (DT); (3) Progress of ball possession (DP); (4) End of the offensive phase (F); (5) Patterns of pitch space position; (6) Centre of the game (CJ); and (7) Spatial patterns of teams' interaction (CEI).

The first four criteria relate to behaviors of the observed team's players, while the fifth is a structural criterion dividing the pitch into 12 zones or categories. The sixth and seventh criteria characterize interaction contexts on micro and macro scales, respectively, taking into account relations of opposition and cooperation between teams and players.

Table 2: SoccerEye Observation Instrument ${ }^{25}$.

\begin{tabular}{|c|c|c|c|}
\hline Criteria & Sub-criteria & $\mathrm{N}^{\circ}$ categories & Categories \\
\hline \multirow{2}{*}{$\begin{array}{l}\text { Start of the offensive } \\
\text { phase/ball recovery (BR) }\end{array}$} & $\begin{array}{l}1.1 \text { Direct/ } \\
\text { Dynamic ball } \\
\text { recovery }\end{array}$ & 4 & $\begin{array}{l}\text { BRi: Interception; BRt: Tackle; BRgk: Intervention of the goalkeeper in the } \\
\text { defensive phase; BRp: Defensive behavior followed by a pass; }\end{array}$ \\
\hline & $\begin{array}{l}1.2 \text { Indirect/ } \\
\text { Static ball } \\
\text { recovery }\end{array}$ & 6 & $\begin{array}{l}\text { BRst: Start/restart of the offensive phase; BRv: Opponent's violation of the laws } \\
\text { of the game; BRc: Corner kick; BRgki: Goal kick; BRdb: Dropped ball; BRti: } \\
\text { Throw-in }\end{array}$ \\
\hline $\begin{array}{l}\text { Development of defense/ } \\
\text { attack transition-state } \\
\text { (DT) }\end{array}$ & & 14 & $\begin{array}{l}\text { DTpsp: Positive short passing; DTnsp: Negative short passing; DTplp: Positive } \\
\text { long passing; DTnlp: Negative Long Passing; DTpcr: Positive Crossing; DTncr: } \\
\text { Negative Crossing; DTrb: Running with the ball; DTd: Dribbling (1x1); DTbc: } \\
\text { Ball control; DTdu: Duel; DTs: Shooting; DTns: Opponent's intervention with } \\
\text { no Success; DTogk: Intervention of the goalkeeper in the offensive phase; } \\
\text { DTdgk: Intervention of the goalkeeper in the defensive phase }\end{array}$ \\
\hline
\end{tabular}




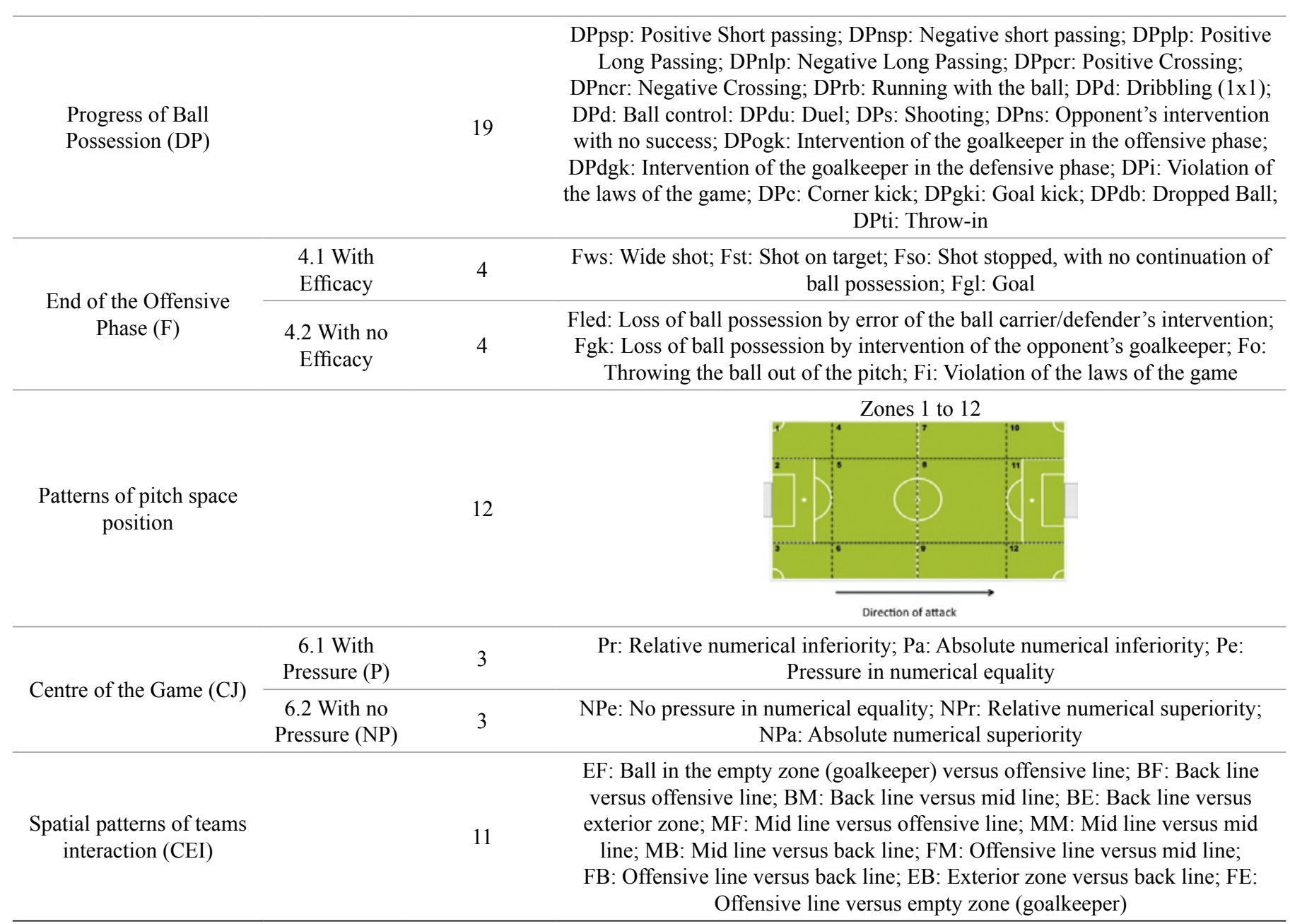

\section{Recording Instrument:}

To record offensive sequences, we used an adaptation of SoccerEye recording software (v 3.2, October 2012) $)^{30}$. The software simultaneously enables visualization and recording of players' actions; it is a versatile and adaptable tool, including contextual variables such as "match status" and "duration of the offensive sequence." SoccerEye's user manual contains definitions and guidelines for its use, helping the viewer perform more affordable, reliable data collection.

Before recording behaviors, field areas, and contexts of players/team's interactions, the observer recorded match status, duration of the attack sequence, and two OSCS variables ${ }^{19,24}$ were also included - the "number of players involved" and the "number of touches on the ball" (Figure 2).

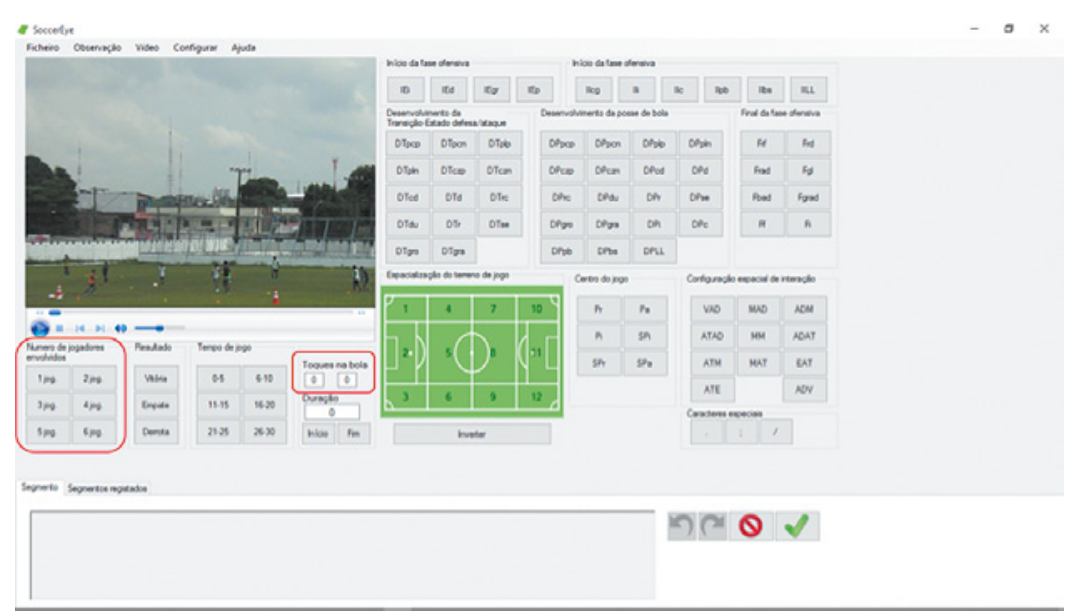

Figure 2. Adaptation of SoccerEye recording instrument ${ }^{30}$. 


\section{Data quality:}

SDIS-GSEQ software (version 5.0.77) 311 $^{31}$ was used to determine inter- and intra-observer reliability through the value of Kappa de Cohen $(\mathrm{k})^{21}$. Observers twice (with an interval of 15 days) analyzed the first 45 minutes of a football game. Values for inter-observer reliability ranged from 0.79 to 0.99 , while values for intra-observer reliability ranged from 0.91 to 0.96 . Therefore, according to Bakeman, Gottman, Portal, Anguera, and Villaseñor ${ }^{32}$, the study data shows good reliability.

\section{Statistical Analysis}

Shapiro-Wilk and Levene tests were performed to verify the normality and homogeneity of variances, respectively, of data related to variables belonging to the OSCS. Once the data did not show normal distribution, a descriptive statistic (median and range) and the Mann-Whitney test were employed to characterize and compare simple and composite indicators of the OSCS (dependent variables) between the two SSCGs (MPG and PTG as independent variables). The significance level of $5 \%(p<$ 0.05 ) was adopted. Statistical analysis was performed with the SPSS 20.0 program.

Using SDIS-GSEQ software (v5.0.77, 2010) $)^{31}$, we conducted a Lag Sequential Analysis, which enables identification of teams' offensive patterns during SSCGs. Lag Sequential Analysis allows identification of behavioral patterns more likely to occur than those dependent on chance, assuming that behaviors are probably repeated in a football match with some frequency and that their sequences are visible in the match $^{33}$.

Therefore, a retrospective analysis of the ten behaviors previous to the attack's end, assuming indicator categories of offensive efficacy (criterion 4) in SoccerEye as conduct criteria. Through selection of respective conduct criteria, analysts counted the times that a certain conduct, considered an object conduct, succeeds that conduct retrospectively, setting the standard conduct (max-lag). The $\mathrm{z}$-score value $(\mathrm{z} \geq 1.96, p \leq 0.05)$ determines the significance level between those conducts, thus detecting teams' offensive patterns during different SSCGs. Sackett ${ }^{34}$ conventional rules, used to determine maximum delay, were not applied.

\section{Results}

\section{Characterization of offensive sequences}

Table 3 shows results of simple and composite indicators of performances belonging to the OSCS. All performance indicators showed statistically significant differences, with the exception of composite indicators "Players involved/Duration" $(p=0.301)$ and "Ball Touches/Duration" ( $p=0.055)$.

Regarding simple performance indicators, the MPG had longer offensive sequences ( $p=0.005$ ), with more players involved in attacks $(p<0.001)$, besides a larger amount of ball touches $(p=0.011)$ and passes performed $(p<0.001)$. The PTG had a greater amount of shots on the opponent's goal $(p<0.001)$.

As for composite indicators, the MPG obtained a larger number of passes per time $(p<0.001)$, passes performed by players involved $(p<0.001)$, and by ball touches $(p<0.001)$. In the PTG, there occurred a greater number of ball touches by players involved in offensive sequences $(p=0.003)$ and a greater number of goals scored by shots performed $(p<0.001)$.

Table 3: Indicators of performance that characterize the offensive sequences in different Small-Sided and Conditioned Games.

\begin{tabular}{|c|c|c|c|c|c|c|}
\hline \multirow{2}{*}{$\begin{array}{l}\text { Performance } \\
\text { Indicators }\end{array}$} & \multicolumn{3}{|c|}{$\begin{array}{l}\text { Maintaining Ball } \\
\text { Possession Game }\end{array}$} & \multicolumn{3}{|c|}{$\begin{array}{l}\text { Progression to the } \\
\text { Target Game }\end{array}$} \\
\hline & Median & Min. & Max. & Median & Min. & Max. \\
\hline $\begin{array}{l}\text { Duration of Ball } \\
\text { Possession (s) }\end{array}$ & $15,00^{*}$ & 2 & 94 & $11,00^{*}$ & 2 & 86 \\
\hline Players Involved & $4,00^{*}$ & 1,0 & 7,0 & $3,00 *$ & 1,0 & 6,0 \\
\hline Ball Touches & $8,00^{*}$ & 1,0 & 32,0 & $6,00^{*}$ & 1,0 & 22,0 \\
\hline Passes & $4,00 *$ & 0,00 & 21 & $2,00 *$ & 0,00 & 9 \\
\hline Shots & $0,00 *$ & 0,00 & 2,0 & $0,00 *$ & 0,00 & 2,0 \\
\hline $\begin{array}{l}\text { Players Involved/ } \\
\text { Duration }\end{array}$ & 0,27 & 0,06 & 1,00 & 0,25 & 0,04 & 0,67 \\
\hline $\begin{array}{l}\text { Ball Touches/ } \\
\text { Duration }\end{array}$ & 0,51 & 0,17 & 1,25 & 0,58 & 0,06 & 2,00 \\
\hline Passes/Duration & $0,25^{*}$ & 0,00 & 0,67 & $0,18^{*}$ & 0,00 & 0,43 \\
\hline $\begin{array}{c}\text { Ball Touches/ } \\
\text { Players Involved }\end{array}$ & $2,00^{*}$ & 1,00 & 5,33 & $2,25^{*}$ & 1,00 & 13,00 \\
\hline $\begin{array}{l}\text { Passes/Players } \\
\text { Involved }\end{array}$ & $1,00^{*}$ & 0,00 & 3,50 & $0,66^{*}$ & 0,00 & 2,00 \\
\hline $\begin{array}{l}\text { Passes/Ball } \\
\text { Touches }\end{array}$ & $0,50 *$ & 0,00 & 0,80 & $0,33^{*}$ & 0,00 & 0,80 \\
\hline Goal/Shots & $0,00^{*}$ & 0,00 & 1,0 & $0,00 *$ & 0,00 & 1,00 \\
\hline $\begin{array}{c}\text { Offensive } \\
\text { Sequences (Total) }\end{array}$ & & 173 & & & 196 & \\
\hline
\end{tabular}

* Statistically significant difference between the Maintenance of Ball Possession Game and the Progression to the Target Game $(p<0,05)$.

\section{Analysis of offensive patterns}

Figure 3 displays offensive patterns that resulted in wide shots (Figure 3A) and in goals scored (Figure 3B) in the MPG. Shots in the MPG tended to occur in the central path of the offensive sector (Fws: $\mathrm{z}=2.85 ; \mathrm{Fgl}: \mathrm{z}=3.75$ ) or in the left path of the offensive sector (Fws: $z=2.05$ ). Wide shots tended to be preceded by a positive short pass $(\mathrm{z}=3: 58)$ or a positive crossing $(\mathrm{z}=4.99)$, both during progress of ball possession (Figure 3A). Goals scored strongly tended to occur before a positive short pass $(\mathrm{z}=2.89)$, which was in turn preceded by a positive crossing $(z=5.17)$, also in progress of ball possession (Figure 3B).

Figure 4 displays offensive patterns that resulted in wide shots (Figure 4A), in shots on target (Figure 4B), and in goals scored (Figure 4C) in the PTG. For offensive sequences that resulted in wide shots (Fws) in the PTG, it was possible to identify offensive patterns with behaviors in progress of ball possession; these tended to occur after an opponent's 


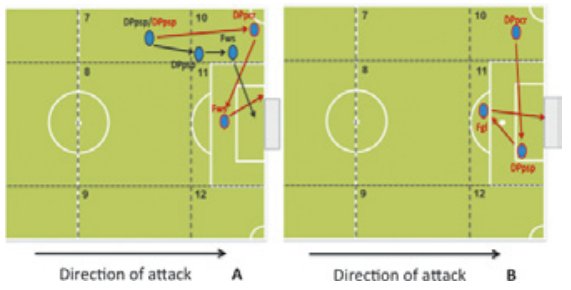

Figure 3. Illustration of the offensive patterns that resulted in a wide shot (A) and in goals scored (B) in the Maintenance of Ball Possession Game. See Table 1.

intervention with no success $(\mathrm{z}=3.16)$, preceded by a negative short pass $(\mathrm{z}=3.08)$. Wide shots were preceded by a goalkeeper intervention (DPdgk; $z=2.44$ ) after a shot (DPs; $\mathrm{z}=2.36$ ), when these behaviors were preceded by a positive long pass $(\mathrm{z}=2.81)$ (Figure $4 \mathrm{~A})$.

As for offensive sequences ending in shots on target (Fst), these tended to be preceded by a positive long pass $(z=3.16)$ after running with the ball $(\mathrm{z}=2.44)$, both in development of defense/attack transition-state. Shots preceded by dribbling $(\mathrm{z}=3.76)$ and by running with the ball $(\mathrm{DPrb} ; \mathrm{z}=2.19)$ in progress of ball possession could also be detected. Another offensive pattern indicated shots preceded by a positive short pass ( $z=4: 41)$ after the goalkeeper's intervention in the defensive phase $(\mathrm{z}=3.48)$ (Figure 4B). Shots on target were preceded by a defensive behavior followed by a pass $(\mathrm{BRp} ; \mathrm{z}=3.32)$, demonstrating shorter offensive sequences.

Goals scored in the PTG tended to occur from an unsuccessful opponent's intervention $(\mathrm{z}=2.87)$, preceded by a shot $(z=2.02)$ or a negative short pass $(z=2.02)$ in development of defense/attack transition-state (Figure 4C); another pattern showed that the shot also tends to occur after a goalkeeper's intervention $(\mathrm{z}=2.66)$, from a shot in development of ball possession $(z=2.59)$ (Figure 4C). Detected also were goals scored after a recovery of ball possession by tackle (BRt; $z=2.07)$ or a positive crossing in Development of defense/attack transitionstate $(\mathrm{z}=3.34)$.

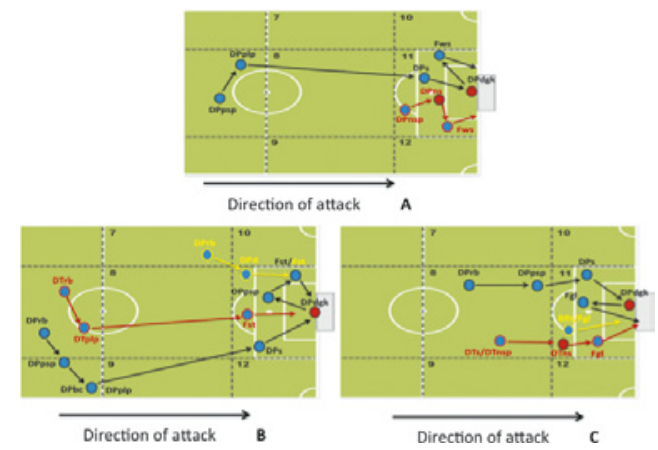

Figure 4. Illustration of offensive patterns that resulted in wide shot (A), in shot on target (B) and in goal scored (C) in Progression to the Target Game. See Table 1 .

\section{Discussion}

This study analyzed the influence of rules manipulation on teams' offensive patterns in different SSCGs. These results showed that MPG rules influenced the emergence of offensive sequences of long duration, with a large number of players involved and with a great amount of touches on the ball and passes made. One possible explanation for this occurrence is the manipulated rule attributing extra points to the team that could replace five passes without returning the ball to the player who had just made the pass (Rule 3), and especially the rule that limited the minimum amount of passes required for shooting (Rule 4). Corroborating this study, Almeida, Ferreira, and Volossovitch ${ }^{19}$ found that manipulation of a rule that defines a minimum number of passes required for a shot tends to condition teams to self-organize so that they opt to attack by prioritizing maintenance of ball possession and circulation of the ball over the pitch, requiring collective construction of offensive actions.

Regarding performance's composite indicators, observers could see that MPG teams had a higher rate of ball transmission among players (Passes/Duration) and a greater contribution by players of ball circulation (Passes/Players involved). Through variable Passes/Ball touches in the MPG, teams used a play style that prioritized exchange of passes among players, adopting a method of positional attack ${ }^{35}$. The rule that assigns a number of points to a team if they circulate the ball from one side path to the other encourages them to do so constantly, to create an advantageous situation for scoring or advancing through offensive game space.

Results from the detection of offensive patterns assist in confirming that teams seek to choose a method of attack that prioritizes maintenance of ball possession. Offensive patterns detected in the MPG consisted largely of behaviors to develop ball possession, prioritizing positional attack by using side paths. MPG rules eventually inhibited the emergence of individual behaviors, enabling a collective attack with more players' participation.

These results corroborate findings by Lizana, Reverdito, Brenzikofer, Macedo, Misuta, and Scaglia ${ }^{20}$, who found that in maintenance possession games, players create favorable situations to score a goal only after ball circulation, in search of a clear space to shoot. Use of side bands in the MPG game field probably facilitated ball circulation, since, when occupying these side paths, players successfully increased the width of effective play-space, thus conducting tactical principles that favor maintenance of ball possession as a spatial principle ${ }^{36}$.

Regarding the PTG, manipulated rules influenced the emergence of faster offensive sequences, in which teams seek faster progression, attempting to take advantage of the opposing team's defensive unbalance, thus making more shots. Almeida, Ferreira, and Volossovitch ${ }^{19}$ observed that rules limiting the amount of ball touches (two) per player influence fast advance, enabling a greater number of shots. However, in this study, offensive sequences' shorter duration seemed to be influenced by manipulation of the rule that constrains the direction of passes toward the opposing goal (Rule 1), but not by the rule that limits the minimum amount of ball touches per player, as used by the authors.

In these games, players sought to intervene more with the ball (Ball touches/Players involved), most likely because of a nonexistent rule that limits the amount of ball touches per 
player. In addition, shots tended to be more effective (Goal/ Shots), probably because faster progression through the field seems to help the team take advantage of the opposing team's possible defensive unbalance. However, Almeida, Ferreira, and Volossovitch ${ }^{19}$ found that a rule that conditions performance of an attack with greater player participation, like the rule that limits the number of passes required to perform a shot, tended to influence shots' greater effectiveness. One possible explanation for this divergence is that the MPG, in this study, had a rule that determined the minimum number of passes needed to shoot and a rule that limited the amount of touches on the ball per player, difficult in both performance of shots as well as their effectiveness.

Offensive patterns in the PTG tended largely to occur in the development of defense/attack transition-state from faster attacks, in which teams look for ball progression through direct connections by a long pass, or through individual behaviors such as a running with the ball and dribbling.

Detection of shots made immediately after a direct ball recovery showed how rules of the game tended to encourage emergence of fast attacks. One possible explanation for emergence of shots on target after a direct ball recovery is that teams can have greater difficulty making passes only toward the opposing goal (rule manipulated in SSCG), thus increasing the probability of losing ball possession in areas close to their own goal. Dellal, Chamari, Owen, Wong, D. Lago-Peñas, and Hill-Haas ${ }^{18}$ observed that manipulation of a rule that conditions the increase of games' dynamics and intensity might influence the effectiveness of passes and loss of ball possession.

With this study's results, we found that manipulated rules in both SSCGs (MPG and PTG) influenced the emergence of opposite play conditions. MPG rules constrained teams to maintain ball possession and circulate it to unbalance the opposing team's defensive organization. The PTG influenced the emergence of faster attacks, when the teams tended to advance quickly through the field to take advantage of the opponent's momentary defensive unbalance. Almeida, Ferreira, and Volossovitch ${ }^{19}$ found that the manipulated rules in their investigation, rules of "two touches" and "four passes," also caused different self-organizing processes in teams, corroborating our findings.

Importantly, however, we highlight that this research sought to use two rules: one that limits each player's ball touches and another that limits the number of passes required to shoot to the opponent's goal, all in the same SSCG (MPG). These two rules were used in MPG in order to condition the teams to adopt a play style prioritizing ball possession through quick passes, promoting highly dynamic offensive sequences. As we know, match dynamics are increasingly faster in today's football, with a higher rate of passes $^{37}$; thus, teams tend to have greater difficulty creating finalization situations, possibly due to choosing more defensive play strategies, which require greater collective work $^{38-40}$. Therefore, when choosing an offensive method that prioritizes maintenance of possession, players and teams need to unbalance the opposing team's defensive organization through faster ball circulation, with greater player participation in sustained attacks.
Therefore, we found that the manipulation of games rules caused distinct self-organizing processes in teams. Coaches may choose to use both games in training, since offensive effectiveness will occur in terms of how teams can switch methods and play styles, imposing their plays in different match contexts ${ }^{26}$.

\section{Conclusion}

With this investigation, we concluded that players and teams tend to self-organize according to games rules used in SSCGs. The MPG rules tended to influence the emergence of offensive patterns in the progress of ball possession, inducing positional attacks, with more players participating and using, preferably, side paths. The PTG rules tended to influence the emergence of faster offensive sequences through long passes and individual behaviors.

The amount of players and teams analyzed can be a limitation of the present study. Therefore, future studies should investigate whether players and teams in different categories (U-13 and $\mathrm{U}-15$, for example) seek to self-organize in different ways, depending on rules manipulation. However, this study provides important information for coaches, since the knowledge about the influence of key tasks constraints manipulation may help them in shaping their teams' specific tactical behaviors.

\section{References}

1. Duarte R, Araújo, D Correia V, Davids, K. Sports Teams as Superorganisms. Sports Med. 2012; 42(8): 633-642.

2. Davids K, Araújo D,Shuttleworth R. (2005). Applications of dynamical system theory to Football. In T. Reilly, J. Cabri and D. Araújo (Eds.), Science and Football V (pp. 556-569). Oxon: Routledge.

3. Costa IT, Guilherme Oliveira J, Garganta J. Para um futebol jogado com ideias: Concepção, treinamento e avaliação do desempenho tático de jogadores e equipes. Curitiba: Appris; 2015.

4. Davids K, Araújo D. A abordagem baseada nos constrangimentos para o treino desportivo. In D. Araújo (Ed.), O contexto da decisão-A acção táctica no desporto (pp. 37-60). Lisboa: Visão e Contextos; 2005.

5. Gibson JJ. The ecological approach to visual perception. Hillsdale: Lawrence Erlbaum Associates: 1979.

6. Silva P, Garganta J, Araújo D, Davids K, Aguiar P. Shared knowledge or shared affordances? Insights from an ecological dynamics approach to team coordination in sports. Sports Med. 2013; 43(9): 765-772.

7. Riley MA, Richardson MJ, Shockley K, Ramenzoni VC. Interpersonal synergies. Front Psychol. 2011; 2.

8. Passos P, Araújo D, Davids K, Shuttleworth R. Manipulating constraints to train decision making in rugby union. Int J Sports Sci Coach. 2008; 3(1): 125-140.

9. Davids K, Araújo D, Correia V, Vilar L. How small-sided and conditioned games enhance acquisition of movement and decision-making skills. Exerc Sport Sci Rev. 2013; 41(3): 154-161. 
10. Hill-Haas SV, Dawson B, Impellizzeri FM, Coutts AJ. Physiology of small-sided games training in football. Sports Med. 2011; 41(3): 199-220.

11. Clemente F, Couceiro M, Martins FM, Mendes R. The usefulness of small-sided games on soccer training. JPES. 2012; 12(1): 93-102.

12. Castelo J. (2003). Futebol: Guia prático de exercícios de treino. Lisboa: Edição Visão e Contextos.

13. Reverdito RS, Scaglia AJ, Paes RR. Pedagogia do esporte: panorama e análise conceitual das principais abordagens. Motriz: J. Phys. Ed. 2009; 15(3): 600-610.

14. Júlio L, Araújo D. Abordagem dinâmica da acção táctica no jogo de futebol. In D. Araújo (Ed.), O Contexto da Decisão: A Acção Táctica no Desporto. Lisboa: Visão e Contextos; 2005 p. 157-178.

15. Folgado H, Lemmink KA, Frencken W, Sampaio J. Length, width and centroid distance as measures of teams tactical performance in youth football. Eur J Sport Sci. 2014; 14(sup1): S487-S492.

16. Silva P, Duarte R, Sampaio J, Aguiar P, Davids K, Araújo D, Garganta J. Field dimension and skill level constrain team tactical behaviors in small-sided and conditioned games in football. J Sport Sci. 2014; 32(20): 1888-1896.

17. Silva P, Esteves P, Correia V, Davids K, Araújo D, Garganta J. Effects of manipulations of player numbers vs. field dimensions on inter-individual coordination during small-sided games in youth football. Int J Perform Anal Sport. 2015; 15(2): 641-659.

18. Dellal A, Chamari K, Owen AL, Wong DP, Lago-Peñas C, HillHaas S. Influence of technical instructions on the physiological and physical demands of small-sided soccer games. Eur J Sport Sci. 2011; 11(5): 341-346.

19. Almeida $\mathrm{CH}$, Ferreira AP, Volossovitch A. Manipulating task constraints in small-sided soccer games: Performance analysis and practical implications. The Open Sports Sciences Journal. 2012; 5: 174-180.

20. Lizana CJR, Reverdito RS, Brenzikofer R, Macedo DV, Misuta MS, Scaglia AJ. Technical and tactical soccer players' performance in conceptual small-sided games. Motriz: J. Phys. Ed. 2015; 21(3): 312-320.

21. Sánchez-Algarra P, Anguera MT. Qualitative/quantitative integration in the inductive observational study of interactive behavior: impact of recording and coding among predominating perspectives. Qual Quant. 2013; 47(2): 1237-1257.

22. Anguera MT, Villaseñor AB, Mendo AH, López JLL. Diseños observacionales: ajuste y aplicación en psicología del deporte. Cuadernos de psicología del deporte. 2011; 11(2): 63-76.

23. Bayer C. O ensino dos jogos desportivos colectivos. Paris: Vigot; 1994.

24. Almeida CH, Ferreira AP, Volossovitch A. Offensive sequences in youth soccer: effects of experience and small-sided games. J Hum Kinet. 2013; 36(1): 97-106.

25. Barreira D, Garganta J, Prudente J, Anguera MT. Desenvolvimento e validação de um sistema de observação aplicado à fase ofensiva em Futebol: SoccerEye. Rev Port Cien Desp. 2012; 12(3).

26. Machado JC, Barreira D, Garganta J. Eficácia ofensiva e variabilidade de padrões de jogo em futebol. Rev Bras Educ Fís Esporte. 2013; 27(4): 667-677.

27. Hughes M, Churchill S. Attacking profiles of successful and unsuccessful teams in Copa America 2001. In T. Reilly, J. Cabri and
D. Araújo (Eds.), Science and football V: The Proceedings of the Fifth World Congress on Science and Football; 2005. p. 222-228.

28. Garganta JM, Marques A, Maia J. Modelação táctica do jogo de futebol: Estudo da organização da fase ofensiva em equipas de alto rendimento. In J. Garganta (Ed.), A investigaçao em futebol: estudos ibéricos; 2002. p. 51-66. Universidade do Porto: Faculdade de Ciências do Desporto e de Educaçao Física.

29. Hughes M, Franks I. Analysis of passing sequences, shots and goals in soccer. J Sport Sci. 2005; 23(5): 509-514.

30. Barreira D, Garganta J, Castellano J, Anguera MT. SoccerEye: A software solution to observe and record behaviors in sport settings. The Open Sports Sciences Journal. 2013; (6): 47-55.

31. Bakeman R, Quera V. Analyzing interaction: Sequential analysis with SDIS and GSEQ: Cambridge University Press; 1995.

32. Bakeman R, Gottman JM, Portal MDG, Anguera MT, Villaseñor AB. Observación de la interacción: introducción al análisis secuencial: Morata; 1989.

33. Anguera MT. Metodología de la Observación en las ciencias Humanas. Madrid: Cátedra; 1992.

34. Sackett GP. The lag sequential analysis of contingency and cyclicity in behavioral interaction research. In J. Osofsky (Ed.), Handbook of infant development. New York: Wiley; 1979. p. 623-649.

35. Castelo J. Futebol-A organização do jogo. Lisboa: Edição do autor; 1996.

36. Costa IT, Garganta J, Greco PJ, Mesquita I. Princípios Táticos do Jogo de Futebol: conceitos e aplicação. Motriz: J. Phys. Ed. 2009; 15(3): 657-668.

37. Wallace JL, Norton KI. Evolution of World Cup soccer final games 1966-2010: Game structure, speed and play patterns. J Sci Med Sport. 2014; 17(2): 223-228.

38. Barreira D Garganta J, Castellano J, Prudente J, Anguera MT. Evolución del ataque del ataque en el fútbol de élite entre 1982 y 2010: aplicación del análisis secuencial de retardos. Rev Psicol Deporte. 2014; 23(1): 139-146.

39. Barreira D, Garganta J, Castellano J, Machado J, Anguera MT. How elite-level soccer dynamics has evolved over the last three decades? Input from generalizability theory. Cuadernos de Psicología del Deporte. 2015; 15(1): 51-62.

40. Bloomfield J, Jonsson G, Polman R, Houlahan K, O’Donoghue P. Temporal Pattern Analysis and its Applicability in Soccer. In L. Anolli, S. D. Jr, M. S. Magnusson and G. Riva (Eds.), The Hidden Structure of Interaction: From Neurons to Culture Patterns Amsterdam: IOS Press; 2005. p. 238-251.

\section{Acknowledgments}

We gratefully acknowledgment the support of Fundação de Ampara à Pesquisa do Estado do Amazonas (FAPEAM).

We gratefully acknowledge the support of two Spanish government projects (Ministerio de Economía y Competitividad): (1) La actividad física y el deporte como potenciadores del estilo de vida saludable: Evaluación del comportamiento deportivo desde metodologías no intrusivas [Grant number DEP2015-66069-P]; (2) Avances metodológicos y tecnológicos en el estudio observacional del comportamiento deportivo [PSI2015-71947-REDP]; and the support of the Generalitat de Catalunya Research Group, GRUP DE RECERCA I INNOVACIÓ EN DISSENYS (GRID). Tecnología i aplicació multimedia i digital als dissenys observacionals [Grant number 2014 SGR 971]. 


\section{Corresponding author}

João Cláudio Machado.

Federal University of Amazonas, Faculty of Physical Education

and Physiotherapy, Brazil; Av, General Rodrigo Octávio, 3000; Campus

Universitário; Manaus/AM

Email: joaoclaudiomachado@gmail.com

Manuscript received on April 17, 2016

Manuscript accepted on August 02, 2016

(c) (i)

Motriz. The Journal of Physical Education. UNESP. Rio Claro, SP, Brazil

- eISSN: 1980-6574 - under a license Creative Commons - Version 3.0 